\title{
'Are You Playing God?': Synthetic Biology and the Chemical Ambition to Create Artificial Life
}

\author{
Joachim Schummer
}

\begin{abstract}
Throughout history chemists have faced the accusation of 'playing God' or similar devilish associations, overshadowing all moral judgments of chemistry. The paper provides an ethical analysis of the accusation with focus on Craig Venter's 2010 announcement of having produced the 'first selfreplicating cell'. Against the deeper historical background of the ambitious projects that came to be known as 'synthetic biology', I describe Venter's actual research and its international media reception. Then I analyze both the ethical and theological implications of creating living beings in the laboratory. In conclusion I argue that the Venter case, like many others cases from chemistry before, is a case of unfortunate science-public interaction that mislead both ethics and science.
\end{abstract}

Keywords: ethics of chemistry, synthetic biology, artificial life, playing God, public image of chemistry.

\section{Introduction}

Chemists working on apparently innocent research projects might be surprised if not puzzled when they suddenly face the public accusation of 'playing God'. They probably think: 'I am just doing good science for the benefit of society. How is that related to religion? Why should that be bad?'

Much more than any other science, chemistry carries a heritage of religious presumption and hubris continuing over 2,000 years. Responsible chemists should be particularly aware of their cultural history, cautious about societal provocations and pitfalls, and versed in ethics.

In the Christian tradition, the accusation of 'playing God' was originally applied to the 'Fallen Angels' who would later be called devils under the leadership of Satan. The Book of Enoch, an Apocrypha of the Old Testament written around $300 \mathrm{BC}$ by a Jewish sect in Ethiopia, narrates the story of a 
conspiracy of a group of angels who disobeyed the commands of God and traveled down to Earth in order to mate with human females and build their own reign, in this sense 'playing God'. ${ }^{1}$ The worst crime they committed was revealing to women certain secret crafts, in particular metallurgy and the production of pigments, dyes, and colored stones (glasses). These crafts, which all involve chemical transformations, were secret because they employed knowledge of the 'Primordial Creation'. At the time the text was written, they were actually developed in Alexandria and became the starting point of what was later called alchemy.

The story or myth is remarkable in several regards. First, it explains the origin of human technology through the impact of evil forces. Second, it relates what we would today call chemistry to the divine knowledge of the 'Primordial Creation' and declares it particularly forbidden. Finally, it is the founding myth of the devil, whom Christianity and Islam, unlike Judaism, incorporated in their theology. In some sense, the invention of the devil was the oldest critique of chemistry.

Chemical crafts, alchemy, and eventually chemistry would never get rid of their devilish association in Christian culture and thereby of the accusation of 'playing God' in the sense of changing or imitating the divine creation with the help of demonic forces. ${ }^{2}$ There are numerous cases similar to the one discussed in this paper, such that this theme has overshadowed all public moral judgment of chemistry.

For instance, church father Tertullian in around $200 \mathrm{CE}$ argued that the dying of wool is against God's will and an association with Satan because God had not made colored sheep in the Primordial Creation. Note that he did not argue against weaving because God had not made sheep with woven wool. Instead the general argument, which has ever since been directed against new technologies, applies to essential transformations only. Chemical transformations with their radical changes of material properties, which transcend ordinary experience and are so difficult to explain, have played a central role. Those who tried to change the Creation, that is to produce something 'unnatural' as it was later called, assumed the role of the Creator God, either alone or with satanic help. In alchemy, every 'unnatural' chemical transformation, be it in metallurgy or for the production of medicines or other uses, was suspected to involve demonic forces. Therefore alchemists, up to the 18 th century, felt obliged to explain their successful work as a 'gift of God' or a process helped by good angelic forces (Karpenko 1998).

Nonetheless, from the 14th century onwards, alchemy became the target of critique by many famous European writers (including Petrarch, Chaucer, Erasmus) and artists (including Dürer, Brueghel, Teniers), modifying the demonic myth. ${ }^{3}$ Whether in writing or in painting, they all produced variations of the same theme: a man is tempted by a fiendish alchemist into prac- 
ticing alchemy, becomes obsessed with his work, and eventually ruins his life. In paintings, the obsessed or mad alchemist was usually depicted with worn clothes, disheveled hair, and surrounded by a mass of alchemical laboratory equipment. During the 19th century, writers such as Mary Shelley, Balzac, Dumas, and Hawthorne transformed the 'mad alchemist' into the 'mad scientist', who as a rule was then a chemist or a physician performing chemical experiments. While the 'mad alchemist' was generally unsuccessful in his work, the 'mad scientist' is at first glance successful, but eventually fails either because his work gains uncontrolled and unforeseen momentum or because he has morally perverted ambitions that end in self-destruction. Eventually Hollywood's movie makers were so fond of the topic that they produced hundreds of variations, drawing on the late medieval imagery of the 'mad alchemist' that was first set in motion picture in Fritz Lang's Metropolis (1927). Since then, a chemical laboratory with various types of glassware is in public culture firmly associated with demonic work.

In the literary and artistic traditions the fabrication of simple biological organisms played little role, for reasons explained in Section 2.1. Instead, the creation of human or human-like beings figured prominently, from Mary Shelley's Frankenstein (featuring a mad chemist) to Wells' Doctor Morean (featuring a mad physician). They drew on earlier literary works or myths, such as the Jewish Golem legend and folktales about the alchemical fabrication of a homunculus (Newman 2004). Among all life forms it was only the creation of human life that was at stake and rose the accusation of playing God.

As will be shown in Section 2, only in the 20th centuary did chemists' scientific fascination and the public's moral excitement about the creation of life begin. That culminated in Craig Venter's announcement of having fabricated the first artificial cell in 2010, and a worldwide media response of 'playing God', which echoed critiques of chemistry for more than two thousand years. Section 3 conducts an ethical analysis of that case and the ambitions of synthetic biologists to create life, before I draw general conclusions about unfortunate science-public interactions that have provoked the accusation of 'playing God'. 


\section{From Spontaneous Generation to Synthetic Biology}

\subsection{The spontaneous generation and artful creation of life in early history}

For most parts of the history, and probably in all cultures, the spontaneous generation of simple living beings from inanimate matter was considered a banality by most people. ${ }^{5}$ Whenever some dirt and moisture was incidentally or intentionally mixed together, mold, worms, flies, lice, etc. emerged. Because nobody liked those creatures, they would blame the inadvertency of people who made that vermin, instead of accusing them of 'playing God'.

There was thus ample evidence of spontaneous generation in ordinary life. Also many Holy Scriptures describe it. For instance, in Exodus 8 of Judaism and Christianity, frogs and mosquitos are skillfully produced as plagues against the Egyptians. The Hindu Laws of Manu (I, 45) divides all living beings into five groups according to their origin, one of which is characterized by their spontaneous emergence out of warmth and moisture. Many ancient Greek natural philosophers expressed their views on which elements are necessary for the creation of life. Aristotle even provided a detailed description and explanation of the generation of testaceae.

In the first-century BC textbook on agriculture, the Roman writer Virgil laid down the principles of bugonia, the art of creating honey bees. To illustrate how those views flourished among educated churchmen, I translate from the German Conrad von Megenburg's Book of Nature (ca. 1350):

Bees emerge out of the bellies of young cows [...]. You need to cover the bellies with muck to get bees. Bees also generate from the buried skin of oxen; wasps from the skins of donkeys; Worms out of the muck of pigs; frogs out of turnips or chard; horseflies out of bad air or rotten breath [...]. From the body of dead horses you get wasps and hornets, from the body of donkeys you get a kind of flies called glow worms [...]. Note that the bees that generate from cows propagate, and that their offspring are of similar kind as real bees.

The most detailed early-modern technical description of generating plants and animals, of cross-breeding and improving them for human purposes, is the widely read second edition of Magiae Naturalis (1589) by the Italian Giambattista della Porta (1535-1615). Unlike the first edition it passed Roman censorship without problems, even though it now included a new part on cross-breeding animals, including the production of human-animal hybrids, and techniques for determining the sex of human offspring. One generation later, the English Lord Chancelor Francis Bacon transformed in his utopia New Atlantis (1623) della Porta's material into a grand systematic research project of improving living nature, from basic living beings made 
from the optimized composition of inanimate matter to perfecting human nature. Influential as Bacon's program still is nowadays - from synthetic biology to transhumanism - it then faced neither ethical nor religious criticism.

Religious objections against the idea of creating life in the laboratory arose only after the acceptance of 19th-century theories of evolution, from Lamarck to Darwin. If humans have ultimately emerged through evolutionary processes from simple living beings, the first creation of those beings would potentially produce humans, and thus the laboratory work would have to be considered comparable to divine creation. That critique was forcefully voiced by the French catholic chemist Louis Pasteur (1822-1895), who experimentally worked hard on refusing the possibility of spontaneous generation, in a famous speech of 1864 before the political and intellectual elite of France:

What a triumph, gentlemen, it would be for materialism if it could affirm that it rests on the established fact of matter organizing itself, taking on life of itself; matter which has in it all known forces! [...] What good then would it be to resort to the idea of primordial creation, before which mystery it is necessary to bow? Of what use then would be the idea of a Creator-God? [quoted from Geison 1995, p. 111].

Suddenly the question of spontaneous generation (and intentional creation) of life, which had been considered a banality for millennia, became a religious issue.

\subsection{Chemical ambitions in the 20th century}

Scientists, who used to think that all natural phenomena have a natural cause, continued to believe in spontaneous generation, both at the historical origin of life and in the laboratory under suitable conditions. However by the end of the 19th century all presumed incidences of spontaneous generation had been found to be caused by spores or germs of microorganisms. Moreover, organic chemists had isolated and structurally described a wealth of diverse compounds in biological organisms, many of which were stereoisomers, which proved the chemical complexity of even the simplest life form.

Starting with Nobel laureate Emil Fischer (1852-1919), organic chemistry took a new systematic and visionary approach. ${ }^{6}$ Nowadays he is well known for the structure elucidation of sugars, which he achieved without any spectroscopic means by using the controlled re-synthesis of the natural products and their chemical modification. Rather than just focusing on the naturally produced, he developed a classification of all possible sugars as well as a synthetic repertoire to produce them, in order to find sugars with new or more useful properties, for instance sugars with higher sweetness or as substitutes 
for diabetics. He applied the same strategy to purines (which includes the nucleobases of DNA and RNA as well as many alkaloids), to amino acids, and small peptides.

In the footsteps of Francis Bacon and always eager to collaborate with biologists, Fischer in 1890 envisioned the chemical modification of organisms far beyond the possibilities of breeding and cross-breeding, what a century later would be called metabolic engineering and eventually synthetic biology. For instance, the chemically modified organisms should be able to digest artificial sugars and to produce out of them, with their modified metabolism, new kinds of fatty acids and proteins with desired properties. In 1915 he first called that approach 'chemically synthetic biology'?' Furthermore, in an unpublished lecture delivered to his working group in 1907, he predicted that chemists would soon be able to create life from scratch in the laboratory. With a strange sense of humor, he added that one day chemists would also be able to create humans, including chemistry professors, so that his own profession would eventually become obsolete.

In the following decades many scientists claimed the imminent life creation through public announcements, for instance the physiologist and president of the British Association for the Advancement of Science Edward A. Schaefer (in 1912), the physicists Oliver Lodge (in 1923) and Paul Renno Heyl (in 1930), and the chemistry Nobel laureates Theodor Svedberg (in 1937) and Glenn T. Seaborg (in 1965). The nuclear chemist Seaborg even asserted that it would be achieved within a couple of years.

In his Presidential Address of the American Chemical Society of 1965, Charles C. Price (1913-2001), a physical organic chemist, demanded that "synthesis of life should be a national goal" for chemistry, similar to the prestigious well-funded grand projects of physics during the Cold War (nuclear energy, radar, weapons, and space exploration). Optimistically he proclaimed: "The job can be done - it is merely a matter of time and money". The "economic consequences of such a breakthrough would dwarf those of either atomic energy or the space program. Success could lead to modified plants and algae for synthesis of foods, fibers, and antibiotics, to improved growth or properties of plants and animals, or even to improved characteristics for man himself." (Price 1965, p. 91)

The most visionary and ambitious 20th-century prophet was the British physical chemist James Frederic Danielli (1911-1984), who after his emigration to the US turned for a while to microbiology. In 1970 he hit the headlines for the first time announcing 'the first synthetic cell' that he had produced by recomposing the nucleus, membrane and cytoplasm of three different amoebae into one new organism. A few days after that rather trivial experiment he was again cited in the media, claiming that such work is dangerous and should be controlled by the government - thereby inventing mor- 
al alarmism as PR for science. Soon he became a spokesman for 'synthetic biology', as he first called the then evolving field of genetic engineering and molecular biology in 1975. He also created the by now standard rhetoric of the field, according to which biology would follow the model of chemistry turning from an analytical period of understanding to an synthetic era of making.

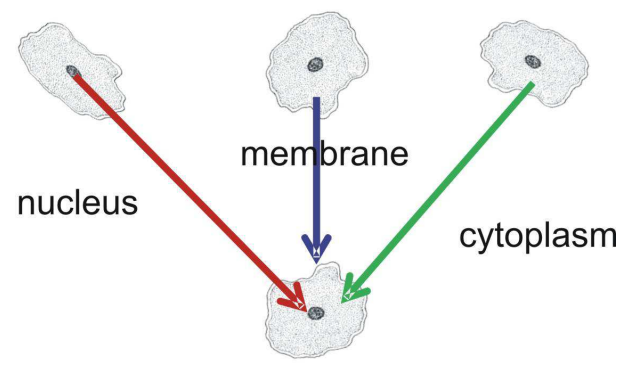

Figure 1: The 'first synthetic cell' by James Frederic Danielli.

Danielli's agenda of Bacon's program includes virtually everything which four decades later the 'new' synthetic biology would again promise to achieve. Relying on genetic determinism he envisioned the complete synthesis of genomes being transferred to host cells, in order to create any desired organism. Once a minimal organism is created, it could arbitrarily be enhanced for food production (e.g., nitrogen fixation, synthesis of essential amino acids or desired proteins), cleaning the environment (e.g., waste water treatment, heavy metal removal, sea water desalination), energy (e.g. the production of oil), medicine (e.g., production of hormones, antibodies, human genes) as well as for data storage and processing (modified neurons for biological computing).

Furthermore, anticipating the later religious sect of transhumanism, he developed an eugenic program for the genetic enhancement of humans. A modified genome would produce humans with higher creativity, intelligence, longevity, and less aggression. Even more, if one produces a set of genetically identical humans, one could conduct better sociological experiments on them for the benefit of our knowledge of society.

Throughout the 20th century, scientists, and chemists in particular, have publicly announced that they soon would be able to create life in the laboratory. While this turned out to be wishful thinking, it revealed three important aspects of their views. First, because their predictions all turned out to be crudely false, their exaggerated views of chemistry's potential undermined their scientific credibility. In fact, hardly any worked in the field, many were physical chemists or physicists with apparently only limited knowledge of 
biology. Second, because the creation of life had in the 19th century turned from a banality to a religious issue, it is likely that they all sought public attention for themselves or their profession through their predictions. This is further supported by the fact that most of them, I assume intentionally, confused the modification of organisms with the creation of life. Third, in a surprisingly naive way they transgressed the border to science fiction as well as moral boundaries by lightheadedly relating the potential fabrication of simple life forms to the creation of humans, either for humoristic reasons (Fischer) or for eagerly attracting public attention to their science (Price and Danielli). In particular, Danielli seemed to have lost any moral sense, not in his scientific work, but in his words that suggested the production of biologically identical humans for human experiments. His unbridled ambition to popularize science through its fantastic power made him look like the protagonist of a mad-scientist movie from Hollywood.

The media reaction was expectable. For instance, the German political magazine Der Spiegel (21 December 1970) displayed on its cover page a naked women sitting in an alchemical retort with modern glassware in the foreground and wrote "Biochemistry: The human being is reconstructed". Its cover story was entitled "Biochemistry: Straight to Hell".

\subsection{The New Synthetic Biology}

At the beginning of the 21st century, two main approaches competed with each other for media attention to become the new synthetic biology: protocell research and synthetic genomics. Both drew on many decades of former research. ${ }^{8}$

Proto-cell research has its roots in chemical evolution, the study of prebiotic conditions on earth that allowed for the stepwise formation of life: from simple organic substances and complex biomolecules to organismic structures and eventually life itself. The classical breakthrough experiment was already conducted in 1952. After heating a gaseous mixture of water, hydrogen, methane, and ammonium for a week and treating it with electrical sparks, Stanley Miller (1930-2007) found a broad spectrum of amino acids as well as sugars, lipids, and components of nucleotides. Further experiments during the next decade could reproduce the formation of nucleic acids and proteins under prebiotic conditions. Studies on the spontaneous formation and dynamics of membranes, vesicles, and micelles, which were already pioneered by Nobel laureate Irving Langmuir (1881-1957) in the early 20th century, added the necessary compartments for organismic metabolism. Since RNA had been found to act not only as a carrier of genetic information but also as an enzyme that might control its own self-replication, much of the research on the chemical origin of life has studied vesicles or micelles filled 
with RNA plus some other ingredients. The idea is to develop a system that shows many or all characteristics associated with life, such as metabolism, self-replication, growth, and chemical exchange with the environment.

Almost unnoticed the field has moved from understanding the historical origin of life under prebiotic conditions to the creation of simple life forms in the laboratory under any condition and by any means. Proto-cell research distinguishes itself from chemical evolution by emphasizing creation at the expense of understanding the origin of life.

Synthetic genomics is an ambitious sub-field of genetic engineering. On the one hand, it draws on metabolic engineering, i.e. the genetic modification of entire protein systems rather than just single proteins, in order to add desired functions or to knock out undesired ones in organisms. That is largely the vision of Emil Fischer which has become possible since about the 1980s. Instead of making bacteria that produce just one new protein, e.g. insulin for diabetes treatment, they insert entirely new functions, for instance, a sensor for a chemical stimulus that triggers a color signal, such that the bacteria turn red whenever the stimulus is present. Encouraged by approaches from software engineering, the success depends on whether such functions are freely combinable in biological organisms, which is of course frequently not the case. On the other hand, synthetic genomics employs the entire repertoire of chemically and biochemically synthesizing and multiplying DNA sequences of maximum length and accuracy, ideally of an entire genome without any errors. Landmark achievements were the syntheses of the genes of the growth hormone somatostatin (1977) and alpha-interferon (1981) by Keiichi Itakura and Michael Edge, respectively. Others include the syntheses of the entire genomes of the poliovirus with 7,000 base pairs (bp) by Eckard Wimmer in 2002, the Spanish influence virus with 13,000 bp by Jeffery Taubenberger in 2005, a mycoplasma bacterium with almost 600,000 bp by Craig Venter's group in 2008. Combining both strands, synthetic genomics aspires to design genomes of organisms with any desired function to be then synthesized in the laboratory and finally 'brought to life'. Again, synthetic genomics distinguishes itself from traditional genetic and metabolic engineering by its emphasis on creating life rather than just modifying existing organisms.

Most synthetic genomicists have, knowingly or not, taken over Danielli's idea of a minimal organism, which includes just enough biological functions (and genetic code) for survival under some standard conditions, and on which then desired functions should be genetically attached. They aspire to reach the minimal organism either by step-wise knocking out of gene sequences of some bacteria or yeast or by designing the minimal genome on their computer. The two approaches are usually called 'top-down' and 'bottom-up', but they rather reflect the different methodologies of biologists and 
software engineers who are both involved. Next we analyze in some detail the most famous example.

\subsection{Craig Venter and the Media}

On 20 May 2010 a press release entitled 'First Self-Replicating Synthetic Bacterial Cell' received worldwide media attention. ${ }^{9}$ It was issued by the J. Craig Venter Institute, a private non-profit genomic research institute in the US, founded and directed by biochemist J. Craig Venter. The institute is one of the most productive and creative ones worldwide. A forerunner institute, Venter's commercial company Celera, became famous in 2001 for beating the international consortium of the Human Genome Project in the race to decode the human genome by employing unconventional methods.

The three-page press release was comparably rich in scientific detail and referred to a research paper published online in Science on the same day (Gibson et al. 2010). However its main message was that scientists had achieved the goal of synthesizing life in the laboratory. How did the media respond?

Not surprisingly, journalists ignored the details and focused solely on the main message. Across all levels, from simplistic tabloids to sophisticated newspapers, they all joined a worldwide chorus: 'Craig Venter is playing God'. A detailed international analysis of online media reports during the following week brought about a surprising geographic pattern according to religious predominance. The chorus was dominant in all Catholic, Anglican, and Hindu countries. In Austria the religious tone was even reminiscent of the former Roman inquisition, relating Venter to witchcraft and the devil. In prevailingly protestant areas of Europe, the most popular association was to Frankenstein, which is only a pseudo-secular version of accusing somebody of aspiring to be Creator. Within Europe only Sweden, Denmark, France, and some parts of Switzerland had nuanced reports with little or no religious allusion, as in the USA, where national pride was unmistakable. Most Christian orthodox countries preferred metaphors from Greek mythology for uttering critique, like Pandora's box, except Russia, where the Frankensteinmotif seems to be popular. Although Judaism and Islam directly or indirectly refer to the same creation myth as Christianity, the playing-God motif was absent in Israel and Arab countries, notwithstanding harsh criticism from Arab commentators. Similarly in China, Japan, and other Buddhist countries, where no comparable creation myth exists.

A follow-up analysis illustrates how uncorrectable public stereotypes are. Through its L'Osservatore Romano, the Vatican immediately issued an official statement on the case, acknowledging the work by the Venter team as an interesting scientific contribution and rejecting all associations with divine 
creation. That notwithstanding, several media, incl. ABC News and Associated Press, titled 'Church warns cell scientists not to play God'.

Let us now have a closer look at what the Venter team actually did and if it was justified to describe the work as producing the first synthetic cell. The paper in question reported only the final step of a series of work on two species of mycoplasma bacteria, let us call them A and B. Mycoplasma bacteria, which cause many serious human infections such as peneumonia, are special bacteria because they have no cell wall and contain a very small genome of only approximately 1 million base pairs. In previous work, the team of 24 scientists from different countries, had, according to a standard procedure known since the 1980s, replaced the genome in species B with that of species A to produce a hybrid bacterium. Luckily the hybrid was able to selfreplicate, which is not typically the rule in such hybrid productions. After a complete genome analysis of A they had further performed a complete genome synthesis of A. All of which had previously been published. The final step was to repeat the production of the hybrid bacterium, now with the synthetic genome, which turned out to be successful.

The proper scientific goal of this work consisted not in producing a hybrid with a synthetic genome, 'synthesizing a self-replicating cell' as the press release suggested. Instead, the goal was to prove the accuracy of the complex genome synthesis, for which the team had developed several new techniques to minimize errors. And the proof of the error-free synthesis was the selfreplication of the hybrid bacterium. In other words, the creation of a selfreplicating cell was not the goal but a means of the scientific work.

In press conferences and various media interviews Venter systematically misrepresented the work of his team. For instance, he argued that the cell was produced out of 'four bottles of chemicals'. As a matter of fact, the team neither produced a cell, nor did they chemically synthesize the genome. They actually bought about 1,000 sequences, each of about $1,000 \mathrm{bp}$, from a commercial DNA-sequence manufacturer who had produced them from enzymatically linking smaller parts that were chemically synthesized. Living yeast cells then combined them to form longer sequences, first to 100 different sequences with each $10,000 \mathrm{bp}$, then to 10 with each $100,0000 \mathrm{bp}$, and eventually to one with about $1,000,000 \mathrm{bp}$.

Furthermore, the hybrids were not produced by literarily replacing the genomes. Instead they mixed synthetic genomes A with cells of species B whose membrane were treated with a kind of soap, such that external bodies could occasionally slip into the cell (Fig. 2). It very rarely happens then that a cell with two different genomes $\mathrm{A}$ and $\mathrm{B}$ incorporated turns through cell division into two cells of which one contains only genome A. If genome A has implemented an antibiotic resistance, all B cells and mixed cells can be killed by the antibiotic, such that only the hybrid cells survive. From the 
unsurprising fact that these cells produced proteins similar to species $\mathrm{A}$, the team concluded that the hybrids would be of species A.

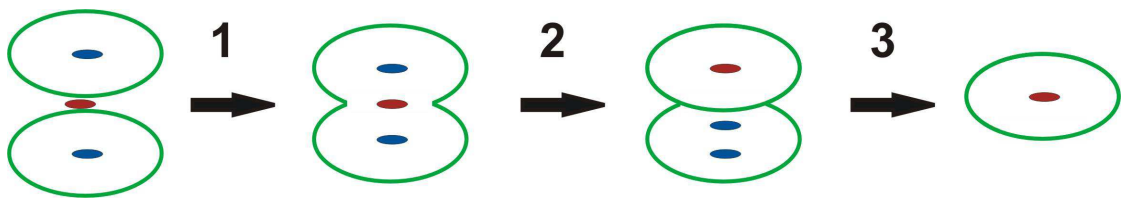

Figure 2: Schematic representation of the experiment by the Venter team. (1) In a mixture of synthetic genomes and surface-treated cells, two cells sometimes merge into one cell that contains two natural and one synthetic genome. (2) Natural cell division of such a cell sometimes results in two cells, one with the synthetic genome alone, the other one with two natural genomes. (3) If the synthetic genome includes an antibiotic resistance, applying the antibiotic kills all the other cells.

In their research paper the authors initially described the procedure more carefully than in the press release and denied that they had synthetically produced an artificial cell. Indeed they wrote that it only looks 'as if' an artificial cell was produced, because they had actually produced only the genome. But then they blurred that difference with computer metaphors arguing that the 'software' (genome) would 'reprogram' or 'reboot' the 'hardware' (rest of the cell) resulting somehow in an artificial cell. While these metaphors are biologically disputable, it seems clear that they had to hold to some naive form of essentialism, according to which the DNA is the essence of life, in order to infer the synthesis of the cell from the synthesis of the DNA.

The Venter case is an illustrative example of how respectable scientific work (here: the almost error-free synthesis of a huge DNA-sequence due to sophisticated control techniques) can be turned into public media excitement through systematic misrepresentation by the authors themselves: by intentionally mixing up means and ends (self-replicability as a means to prove the error free DNA-synthesis), exaggerations (e.g. describing complex biochemical synthesis in living organisms as simple wet chemical synthesis), confusing parts with wholes (DNA and cell), avoiding unwelcome truths (e.g. that genome replacement is a standard procedure of hybridization rather than cell creation), and wrapping up everything in dubious metaphors to hide the confusion.

Moreover, in many interviews Venter argued that the experiment would challenge our philosophical understanding of life and show that 'we' (humans) are information machines, without any further explanation. Because the traditional philosophical understanding of life has largely been about 
human life, it is not clear how the successful hybridization of closely related bacteria can contribute to that. Nor is it clear how the bacteria experiment can revive the old information-machine metaphor that had stimulated the early days of genetic engineering. However, by relating his pretended bacteria creation to human beings through quasi-metaphysical comments, Venter could indirectly point to the idea of creating or modifying humans. Such allusions are sufficient to create media hype and public excitement because they trigger stereotypes that are deeply rooted in Western culture, from the homunculus myth that surrounded alchemy to the Frankenstein myth.

\section{Ethical Analysis}

This section provides an ethical analysis, not about synthetic biology in general but about its ambition to create artificial life as highlighted in the previous sections. ${ }^{10}$ The analysis is confronted with a strange situation that is very unusual in current ethics of emerging technologies. Typically research and development proceeds much faster than the ethical reflection which is lagging behind. In our case, however, the situation seems reverse: Over thousands of years before the 19th century, people had believed that life can easily be made from inanimate matter and that it had frequently been done so (Section 2.1). But nobody had raised any moral or religious objection against that; ethicists (and theologians) had simply been disinterested in the matter. Nowadays we see stimulated media hype and public moral excitement about the artificial creation of life (Section 3.4), although the goal is not yet achieved. The critique is poorly articulated. As if ethics - i.e. the moral reflection on values, norms, obligations, judgments, intentions, virtues, and consequences of actions - did not exist, a broad public expresses their moral concern, if not horror, through the accusation of 'playing God'.

The following subsections look at the artificial creation of life from six different ethical angles. The first three approaches are deontological, i.e. they judge actions independent of their specific consequences, only according to whether they meet or violate certain general obligations. The three corresponding obligations are (1) not 'playing God', (2) respecting the dignity of life, and (3) reverence or responsibility for life. In contrast, the subsequent three approaches, which philosophers call consequentialist positions, judge actions only according to whether their consequences are desired or undesired. Particularly they look at three kinds of risks (i.e., undesired and unintended potential consequences): artificial organisms could (4) interfere with the ecosphere, (5) be misused as bioweapons, and (6) cause harm to laboratory staff and local environment. 


\subsection{The accusation of playing God}

As we have seen above, the dominant media response in Christian countries to scientists who claim or aspire to create an artificial organism in the laboratory is the accusation of 'playing God'. The objection is deeply religious and has meaning only within a religious context that includes a divine creator of all life. If $\mathrm{A}$ accuses $\mathrm{B}$ of playing God, $\mathrm{A}$ means that $\mathrm{B}$ pretends and intends to be like God.

In the Christian tradition that intention came to be the cardinal or worst of all sins, much worse than robbing, raping, child abuse, or murdering. Through the story of the fallen angels, who disobeyed God and tried to establish their own regime on earth, the sin is firmly related to Satan (Section 1). Thus, accusing somebody of playing God is another way of calling him Satan.

The religious prohibition of creating artificial life rests on three assumptions that are all problematic:

1. Historical assumption: All life on earth originated from divine creation. However, most scientists believe that life originally emerged by chemical evolution.

2. Metaphysical assumption: Every natural organism owes its existence indirectly to divine creation in a way that would be circumvented by human life synthesis. However, most theologians, including the Vatican statement cited above, believe that all life originates from God, no matter what humans make in their experiments. Matter might originally be imbued with the potentiality of life or with sperms that can turn into real life under certain conditions. Church Father Augustine explained spontaneous generation in this way already in the fifth century.

3. Psychological assumption: Scientists who try to create life in the laboratory intend to be like God. However, unless they clearly express such an intention, there is little reason to assume that. Note that the sin does not consist in doing something, but in pretending and intending something. If the scientist is an atheist, the assumption is plainly wrong. Somebody who does not believe in the existence and concept of God can hardly intend to be like God.

Since all three assumptions are problematic, it is difficult to understand how the accusation could be meaningfully applied to synthetic biologists by either Christians or atheists. It rather originates from a folk religion of an artisanlike creator God, mixed up with literary myths such as the Frankenstein and homunculus stories. However, as the Venter case illustrates, some scientists subtly play with that folk myth in order to raise media attention for their own research. 


\subsection{Dignity of Life}

A frequent objection against the creation of artificial organisms worries about the dignity of life. If life can be synthesized in the laboratory, it is said that it would lose its dignity, which is considered a bad thing. The objection has been raised throughout the 20th century and recently echoed by many critics of synthetic biology. It is worth considering the argument in detail because it typically comes with hidden assumptions and conceptual confusion.

Note that the argument cannot be applied to individual organisms synthesized in the lab. Because these organisms did not exist and thus could not have any dignity before their synthesis, it is logically impossible that they would lose their dignity by their creation. In order to make sense of the argument, we need to reformulate it so that it applies to kinds of organisms: 'The knowledge that organisms of a certain kind can be synthesized in the lab eliminates their dignity, which is bad.'

There are at least two major problems with the argument. First, it is not clear if simple life forms actually bear any dignity and where that would come from. In the religious creationist reading, the dignity is endowed by divine creation, which is missing in human creation. The argument is then just another version of the playing-God objection that was rejected above (van den Belt 2009). In any secular reading, dignity is ascribed by humans through appreciation and moral respect. However, today's wide use of antiseptics and antibiotics for killing bacteria without the slightest moral concern suggests that humans ascribe no dignity to microorganisms. There is also no historical evidence that humans ascribed dignity to basic living beings before the mid20th century, when philosophers began to develop related ideas to which we will come back in the next section. Starting in the Renaissance, dignity has been ascribed solely to human beings in order to establish respect for humans and natural human rights. For instance in the Kantian tradition, human dignity rests on the moral freedom of humans, opposed to the causal determination of other living and non-living nature.

It seems that the argument relates the life of basic organisms to human life, such that the synthesis of simple life form would affect our understanding of humans and eventually human dignity. Indeed most newspaper commentaries of Venter's hybrid bacterium, as well as Venter himself, tried to establish that relationship - most prominently by the Frankenstein myth. That is however both biological and philosophical nonsense. If a simple organism could be made in the laboratory, that would have no biological implications about how to make a human. Moreover, philosophical traditions derived human dignity from moral and intellectual capacities rather than from biological functions that we might share with other organisms. 
Second, even if simple life forms had some kind of dignity, the argument would not stand ethical scrutiny because it discredits knowledge. Imagine somebody ascribing dignity to a bacterium based on the idea that this bacterium cannot artificially be made. Imagine further that scientists find out that the idea was wrong, that the bacterium can actually be made. The only reasonable ethical response would be to recognize one's mistake, that the ascription of dignity was based on a wrong assumption. In contrast, the argument suggests that such knowledge is bad even if it is true. However, such a position that defends dogmas by discrediting knowledge would hardly count as an ethical standpoint.

If simple life forms can generate from inanimate matter, the natural response would be a shift in one's attitude, as the Scottish biologist John Arthur Thomson already wrote in 1922, "it would increase our appreciation of what is often labeled as 'inert' matter" (Thomson 1922, vol. 1, p. 62).

\subsection{Biocentric Ethics (1): biological individualism}

For most parts of history, Western ethics was anthropocentric, i.e., humans (frequently excluding slaves and women) were the only beings that were considered moral objects in moral deliberations. In accordance with the biblical task that man should rule over Earth (Genesis 1, 28), nonhuman nature, both living and nonliving, lacked any intrinsic value and was considered only instrumental to human interests as long as it was not eradicated. Only during the Enlightenment period the scope of morally relevant objects was extended to include higher animals capable of suffering, in particular by Jean-Jacques Rousseau (1712-1778) in France and Jeremy Bentham (1748-1832) in England.

Truly biocentric approaches, which attribute intrinsic values to all living beings and appreciate them for their own sake in moral consideration, were developed not before the 20th century. Most famously the French-German physician and theologian Albert Schweitzer (1875-1965) developed his theory of 'reverence for life' for which he was awarded the Peace Nobel Prize in 1952. He maintained that all living beings - human and nonhuman, including pathogenic bacteria (!) - share a 'will for life' that establishes in humans the moral emotion of respect or reverence as the fundamental basis of ethics. Similarly, in his The Imperative of Responsibility (1984), the German philosopher Hans Jonas argued that all living beings have an intrinsic purpose, they defend themselves against death and call for protection, from which he derived the fundamental human responsibility for all life.

Can we infer from these classical biocentric approaches ethical objections against the artificial creation of life? Unlike what one would expect at first glance, the answer is a clear No. If the artificial organism meets all the biolog- 
ical criteria for life, as synthetic biologists aspire to achieve, it would deserve the same reverence and responsibility as a natural organism. Moreover, if living beings unlike inanimate matter have intrinsic value, one could even derive the moral obligation to increase that value by turning inanimate matter into life. Thus classical biocentric approaches, which focus on the intrinsic value of biological individuals, would encourage rather than prohibit the artificial creation of life.

\subsection{Biocentric Ethics (2): biological holism}

Unlike the previously mentioned approaches of biocentric ethics, which consider biological individuals to have intrinsic values, there is another branch of environmental ethics that appreciates the biosphere as a whole, a dynamic ecosystem in which individuals only play temporary and exchangeable roles. The difference between both positions echoes two extreme views of the human sphere: individualism (society is an aggregation of independent individuals with certain rights) versus socialism (society is a complex holistic system composed of the interdependencies between exchangeable individuals).

Not surprisingly, biological holism, which is sometimes also called 'deep ecology' and which can be traced back to early 19th-century romanticism, comes with various religious and political flavors, each celebrating its own founder. Yet, from a biological point of view it makes perfect sense to look at life not as an arbitrary aggregation of individuals, but as a dynamic system, both at the local level of ecosystems and the global level of the biosphere. If one considers large time scales, the biosphere undergoes evolutionary changes by its own population dynamics as well as by outer impacts such as natural disasters and eventually human interference.

Biocentric holism, as an ethical approach, ascribes intrinsic values to the ecosphere as a dynamic whole and calls for its protection by sustaining various characteristics, such as species diversity and adaptive flexibility. The call is difficult to justify, though, within a biocentric framework that takes humans as part of the global ecosphere, because that would allow any human interference to count as an acceptable factor of biological evolution. Justifications therefore include the Christian appeal of human stewardship for nature and the anthropocentric appeal that human life depends on its biological environment to be sustained for the sake of humans. Whatever the justification may be: can we derive from biocentric holism moral constraints on the human endeavor of producing artificial organisms?

Humans have ever interfered with the biosphere, from agriculture, horticulture, forestry, and the breeding and domestication of animals to the use of antibiotics, antiseptics, pesticides, and genetic engineering. In some cases, biocentric holism provides clear guidance, for instance against large defor- 
estation of rain forests and huge monoculture production of crops upheld by massive employment of pesticides, both resulting in vast extinction of biological species and instable ecosystems. Also genetic engineering can be problematic if the gene-modified species massively and irreversibly change the ecosystem through direct interaction with other species or through gene exchange on an evolutionary scale. Even though genetic engineering has employed from the beginning 'natural' enzymatic processes for gene insertion, replacement, and modification, the extend of biological gene mobility among species has long been underestimated.

If the artificial organism is equipped with normal DNA or RNA, the problems of genetic engineering will largely repeat. If the DNA or RNA is modified, by chemically modified nucleobases or nucleotides, the possible genetic interactions with the biological environment are hardly foreseeable. If, on the other hand, the artificial organism is composed entirely differently than natural organisms, genetic interactions with the environment becomes unlikely, but such organism might be able to drive out other organisms and thus massively change the ecosystem. To prevent such 'run-away' cases, one could genetically incorporate an invulnerability that allows killing the artificial organisms when they might become a biological thread. However, such in-built vulnerability is not a handy solution for all cases, as synthetic biologists sometimes suggest. If the artificial organism is sufficiently similar to natural organism, the vulnerability could easily spread to natural species with undesired effects on the ecosystem.

Despite the shortcomings regarding its ethical foundation, biocentric holism can give us some moral guidance for the artificial production of life. However, at this point there is hardly more than a rule of thumb: particular precaution is due if the artificial organism is neither very similar to nor very different from natural organisms.

\subsection{Bioterrorism}

A frequently voiced argument against synthetic biology warns of the misuse of dangerous creatures by rogue states or terrorists (e.g., Schmidt 2009). To be sure, the argument points to an important risk. However, one should evaluate the threat with a sense of realism.

It is more than unlikely for several reasons that in the near future somebody would create a new organism from scratch for malign purposes only. First, it is extremely difficult to do, in fact no scientist knows how to do that by now. Second, the research and development would be extraordinarily dangerous (see below), which rules out all amateurish endeavors. Third, there are many malignant micro-organisms in wild life, like the Ebola virus or Bacillus anthracis (anthrax), which could be collected and employed in a much easier 
and less dangerous way based on long term experience with these infectious diseases. Forth, it is much easier to modify existing organisms by standard genetic engineering such that they become malignant. If the presumed rogue state or terrorist had only the slightest sense of proportion for the required effort and the desired effect, they would of course collect or modify natural pathogens.

Nonetheless, bioterrorism remains a threat, not by new organisms from scratch, however, but by classical genetic engineering. Commercial firms offer synthetic gene sequences at rapidly decreasing rates, currently for about 20 US cents per base pair. That makes it cheap and easy to insert into bacteria sequences that code for toxins either as plasmids or as parts of the genome.

Not because of synthetic biology but because of the rapid decay of prices, there is an urgent need for international regulation of gene synthesis companies, their clients, and orders with regard to pathogenic genes. Thus far, there are only some national recommendations and voluntary commitments by companies.

\subsection{Risks for laboratory staff and the environment}

Last but not least, the creation of new and the modification of existing micro-organisms is a high risk for all laboratory staff including the cleaning personnel and the local environment. Ethicists frequently ignore that when they consider scientific research to be done by the individual researcher who might be responsible for his own harm. However, in current laboratory research projects usually dozens of people are involved with different backgrounds in science and safety instruction.

For instance, the synthesis and modification of pathogenic viruses, such as the poliovirus and influenza virus, may improve our medical knowledge but is at the risk of all people involved, including their social environment. Mycoplasma bacteria, which are favorite test organisms in synthetic biology because of their lack of a cell wall, are frequently pathogenic and cause chronic infectious diseases, probably for the same reason. When handling sequences of DNA and RNA for whatever reasons, one should keep in mind that these biopolymers can interfere with the genetic material of humans and other living beings in hardly predictable ways.

When synthesizing a new, hitherto unknown chemical compound, chemists are used to treat it in their laboratory with all precaution, as if it would be highly toxic. Even if one has perfect structural knowledge of the compound, its effects in complex biological contexts are unpredictable. Much stricter safety measures must be applied to research with microorganisms, modified or artificial, and all biological material that is capable of replication because even the smallest amount could multiply in suitable environments. All exper- 
imental settings need to be strictly double-isolated against both the laboratory and the outer environment.

For any such experiments, the research goals should be well balanced against the remaining risks for laboratory workers and the surrounding natural and social environment. One must have good reasons - ones that would be morally acceptable in case of an accident - to justify the research. In would not help much saying, 'I just wanted to try something out'.

\section{Conclusion}

The history of life creation and the way people looked at it is more than puzzling. For thousands of years it was considered a banality that happened everywhere, whether intentionally or not; nobody cared about it or raised any moral or religious concern. Nowadays it is both an overarching goal for many scientists and an outrageous idea for large parts of the public in Christian countries. The reversal of views could not be more extreme. What made this happen?

As pointed out in Section 2.1, evolution theories moved the focus of scientific and moral attention to simple organisms as the potential beginning of life, from which human beings would eventually have emerged. However that cannot provide a full explanation of the public consternation. Both creationist, who do not believe in evolution, and people in secular societies express a similar kind of dismay with the accusation of 'playing God' or imitating Frankenstein, the 'modern Prometheus' as Mary Shelley subtitled her influential novel. Moreover, as we have seen in Section 3.1, the accusation of 'playing God' has no ethical or theological basis, neither within nor without the Christian doctrine. One might instead claim a general shift in the evaluation of life forms during the 20th century supported by environmental movements. However, we are talking here mostly about bacteria that are invisible to the naked eye and beyond the horizon of most people, although about $10^{14}$ bacteria live in every human and approximately $5 * 10^{30}$ on Earth making up most of the biomass (Whitman et al. 1998). Who would actually go as far as Albert Schweitzer and call for reverence to pathogenic microorganisms?

It seems more likely that the public dismay about life creation expresses a diffuse fear and dismay of science in general, and chemistry in particular, that is composed of literary myths epitomized in the mad scientist (Section 1). As we have seen in Section 3, however, the public dismay does not stand up to ethical scrutiny. None of the three deontological approaches (the obligations to not 'play God', to not touch the dignity of life, and to reverence and be 
responsibility for individual organisms) can be used to derive serious objections. Of course the three consequentialist approaches point to important risks (interference with the ecosphere, misuse as bioweapons, and harm to laboratory staff and local environment). However these risks of the creation of artificial organisms do not essentially differ from, are sometimes even minor to, the risk of modifying existing organisms. In sum, it is difficult to find any particular ethical substance behind the public dismay expressed in phrases like 'playing God'.

Unarticulated as these phrases are, they are extremely powerful in creating public moral excitement, with two negative side effects. On the one hand, they distract the public from proper ethical deliberations and issues. Because they express radical rejection, they undermine any dialogue between science and the public. That might even hinder constructive ethical work in which scientists and ethicists ideally work together. On the other hand, they mislead science by pushing the creation of life as an end in itself, because that is exactly what draws public attention and thereby indirectly research funding. Scientists like Price, Danielli, and Venter have been tempted into alluding to these phrases, for instance by confusing 'modification' with 'creation' of life and microorganisms with humans. Venter, as we have seen in Section 2.4, even went further and systematically misrepresented the research of his team, among others by putting the creation of life as the presumed research goal, whereas their hybrid bacterium was actually only a means.

One might think that this is only PR on the surface and does not touch real research. However, several developments suggest that it has also an impact on scientific values. For instance, proto-cell research neglects or even gives up the earlier scientific quest for understanding the origin of life in favor of making something alive, whatever it is and under whatever conditions (Section 2.3). Thereby the epistemic value of understanding, of knowing how and why something happened, is replaced by the technological value of knowing how to do something. In synthetic genomics it is also not clear, whether the enormous efforts at building an organism from scratch improves our scientific understanding of life and its historical origin. The supposed epistemological principle of knowing from making, which was once so successful in organic chemistry, is difficult to apply to whole biological systems. Moreover, it is far from clear whether building an organism from scratch would have any technological advantage over the targeted genetic modification of existing organisms. Thus the effort might even violate the technological value of keeping a reasonable cost-benefit ratio.

Finally, unfortunate science-public interactions do serious harm to the profession of scientists. As the cases of Danielli and Venter illustrate, the literary myths of the fiendish mad scientist, which somehow began with the Book of Enoch 2300 years ago, are deeply entrenched in popular culture and 
can be revived at any time. Minimal allusions suffice to reinforce age-old stereotypes. Chemists, due to their special cultural heritage outlined in the Section 1, are particularly affected and should meticulously avoid any allusion. If they ignore that, because of lack of knowledge about the cultural history or out of selfish desire to be in the focus of public attention, they damage the image of science. In the end neither scientists, nor the public, nor ethicists are happy.

\section{Further Reading}

A much more detailed presentation with background information and hundreds of references, which are here omitted for space reasons, is Schummer 2011, albeit not yet translated into English. More details on Section 2 can be found in Schummer 2003, 2006, 2009. There are numerous anthologies on the societal and ethical aspects of synthetic biology, from earlier ones such as Bedau \& Parke 2009, Schmidt et al. 2009 to Boldt 2016, Hagen et al. 2016.

\section{Notes}

1 On the following see Schummer 2003.

2 In the Christian tradition the accusation of 'playing God' can have different meanings depending on God's role as creator (messing with the Creation/Nature), moral law-giver (giving oneself own moral laws), or ruler of destiny (controlling the course of events). This paper refers only the first meaning.

3 On the following, see Schummer 2006.

4 A rare early exception is Theodore Sturgeon's Microcosmic God (1941), see Schummer 2011, pp. 184-186.

5 On the following, see Lippmann 1933, Farley 1977, Schummer 2009, 2011, chap. 3.

6 On the following, see Schummer 2011, chap. 7, on Fischer see also Johnson 2015.

7 At that time, the term 'synthetic biology' was used to mean a holistic approach in biology, from which Fischer clearly wished to distinguish himself.

8 On the following, see Schummer 2011, chap. 8.

9 On the following, see Schummer 2011, chap. 9.

10 On the following, see Schummer 2011, chaps. 13, 15. 


\section{References}

Bedau M.A. \& E.C. Parke (eds.): 2009, The Ethics of Protocells: Moral and Social Implications of Creating Life in the Laboratory, Cambridge, MA: MIT-Press.

Boldt, J. (ed.): 2016, Synthetic Biology: Metaphors, Worldvierws, Ethics, and Law, Wiesbaden: Springer.

Farley, J.: 1977, The spontaneous generation controversy from Descartes to Oparin, Baltimore: John Hopkins UP.

Geison, G.L: 1995, The Private Science of Louis Pasteur, Princeton: Princeton UP.

Gibson, D. et al.: 2010, 'Creation of a bacterial cell controlled by a chemically synthesized genome', Science, 329, 52-56.

Hagen, K.; Engelhard, M. \& Toepfer, G. (eds.): 2016, Ambivalences of Creating Life: Societal and Philosophical Dimensions of Synthetic Biology, Basel: Springer.

Johnson, J.A.: 2015, 'From Bio-organic Chemistry to Molecular and Synthetic Biology: Fulfilling Emil Fischer's Dream', Proceedings of the International Workshop 'Transformation of Chemistry from the 1920s to the 1960s', 2-4 March 2015, Tokyo, Japan [online available at http://kagakushi.org/iwhc2015/papers/01.JohnsonJeffrey.pdf, accessed: 7 March 2016].

Jonas, H.: 1984, The Imperative of Responsibility, Chicago: University of Chicago Press [German original: Das Prinzip Verantwortung, Frankfurt: Suhrkamp, 1979].

Karpenko, V.: 1998, 'Alchemy as donum dei', Hyle: International Journal for Philosophy of Chemistry, 4, 63-80.

Lippmann, E.O.v.: 1933, Urzengung und Lebenskraft: Zur Geschichte dieser Probleme von den ältesten Zeiten an bis zu den Anfüngen des 20. Jabrhunderts, Berlin: Springer.

Newman, W.R.: 2004, Promethian ambitions: Alchemy and the quest to perfect nature, Chicago: University of Chicago Press.

Price, C.C.: 1965, 'The new era in science', Chemical and Engineering Nerws, 27 September, 90-91.

Schmidt M.: 2009, 'Do I understand what I can create? Biosafety issues in Synthetic Biology', in: M. Schmidt; Kelle, A.; Ganguli-Mitra, A. \& de Vriend, H. (eds.), Synthetic Biology: The Technoscience and its Societal Consequences, Dordrecht: Springer, pp. 81-100.

Schmidt M.; Kelle, A.; Ganguli-Mitra, A. \& de Vriend, H. (eds.): 2009, Synthetic Biology: The Technoscience and its Societal Consequences, Dordrecht: Springer. 
Schummer, J., 2003: 'The Notion of Nature in Chemistry', Studies in History and Philosophy of Science, 34, 705-736.

Schummer, J., 2006: 'Historical Roots of the 'Mad Scientist': Chemists in 19th-century Literature', Ambix, 53, 99-127.

Schummer, J.: 2009, 'The Creation of Life in Cultural Context: From Spontaneous Generation to Synthetic Biology', in: M.A. Bedau \& E.C. Parke (eds.): The Ethics of Protocells: Moral and Social Implications of Creating Life in the Laboratory, Cambridge, MA: MIT-Press, pp. $125-142$.

Schummer, J.: 2011, Das Gotteshandwerk: Die künstliche Herstellung von Leben im Labor, Frankfurt: Suhrkamp.

Thomsons, J.A.: 1922, The Outline of Science, New York: Putnam's Sons.

Whitman, W.B.; Coleman, D.C. \& Wiebe, W.J.: 1998, 'Prokaryotes: the unseen majority', Proceedings of the National Academy of Sciences, 95 (12), 6578-6583.

van den Belt, H.: 2009, 'Playing god in Frankenstein's footsteps: Synthetic Biology and the meaning of life', Nanoethics, 3, 257-268.

Joachim Schummer:

Philosophy Department, Karlsruhe Institute of Technology, Germany; js@byle.org 